\title{
A Study on Communalism and Religious Hatred through The Play "Final Solution"
}

\author{
Pinky Lade \\ Research Scholar \\ Barkatullah Vishwavidyalaya \\ Bhopal, M.P, India \\ pinki.lade@gmail.com
}

This is another hot and burning topic of modern India and that is communalism. We are living in twenty second century but still we indulge ourselves in hate, bloodshed, slaughter, murder on the basis of caste and religion. We live quietly and calmly then suddenly a voice full of hatred arise and we all arise with deadly weapons, guns, and swords in our hands start slaughtering our neighbors, friends, and acquaintances. It is very shameful that we have kept hatred sleeping deep in heart and just at the spark of one tiny incident, it bursts out.

Perhaps Ramalakshmi has experienced that bitterness of religious differences which provoked her to make her research around this burning topic of communalism and riots through the work play Final Solution, by Mahesh Dattani.

Our Country India is always known for its patience, non-violence, humanity, and spirituality from ancient times. The play exposes the evils of communalism. The play sheds light on weakness of human minds, selfishness, and opportunism. The play was written after the demolition of Babri Masjid and the massacre happened as a result. It was actually the game of 
reaction against some action and vice versa. The play talks about the cultural hegemony. It is a story of a Gujarati Family of three generations. It is based on friendly relations between two religions, Hindu and Muslim. The story comprises half a century time taking into account the generations, past and present. This is the story of a Muslim boy, Javed. He becomes victim of an incident and later becomes a trained terrorist. His heart is full of hatred against some other community and feels satisfied doing wrong this and killing people in the area. He was sent to create chaos in a mohalla where a religious procession taken out. He throws stone which results in chaos and ended in killing many people including the Hindu priest. This communal hatred is used by the politicians to fulfil their desires and greed for power and money. Actually they are real culprits of all these riots. They use unemployed youths, give them penny and show them big dreams for achieving something. They use these youths as weapon of destruction when and where it is required.

As per Ms. Ramalakshmi's words in the IJELLH report "The play have a powerful contemporary resonance and it addresses as issue of utmost concern to our society, i.e., the issue of communalism. The play presents different shades of the communalist attitude prevalent among Hindus and Muslims in its attempt to underline the stereotypes and cliches influencing the collective sensibility of one community against another. What distinguishes this work from other plays written on the subject is that it is neither sentimental in its appeal nor simplified in its approach. It advances the objective candor of a social scientist while presenting a mosaic of diverse attitudes towards religious identity that often plunges the country into inhuman strife. Yet the issue is not moralized as the demons of communal hatred are located not out in the street but deep within us." 
The play examines the attitude of three generations of a middle class Gujarati Business class family. The playwright explores the mindsets in the different situations. The bad old incidences imprints in your mind and remains with you for the lifetime. In a crunch and emergency situation of like that happened in the past stops you being human, stops you from saving life of your neighbors and friends who were with you for years.

\section{Conclusion:}

The research paper of Ramalakshmi examines in depth the human behavior through the characters of the play, The Final Solution. Ramalakshmi goes through each character separately and reads their behavior and mind, how it behaves the way it is behaving; Why it behaves like that in the emergency situation of riots. Human beings are such that bad experiences leave permanent footprints in their minds. Good deeds are forgotten easily. Ramalakshmi in the end says that though the play sheds light on the communal issues, hatred, agony and sufferings but it does not provide the solution for communal hatred that sparks at the blink of eyes. It is welldocumented research paper on the topic of riots and human behavior and nature. 


\section{References}

Chaudhuri Asha Kuthari .Contemporary Indian writer in English : Mahesh Dattani (Delhi Foundation Books, 2005)

RAMALAKSHMI'S, Mrs. P.. Communal Harmony In Mahesh Dattani's FinalSolutions. SMART MOVES JOURNAL IJELLH, [S.1.], v. 2, n. 2, p. 12, june 2014. ISSN 2582-3574. Available at: 〈https://ijellh.com/OJS/index.php/OJS/article/view/3247〉. Date accessed: 11 may 2018.doi: https://doi.org/10.24113/ijellh.v2i2.3247. 